\title{
RESEARCH ARTICLE Optimization of Chitosan Concentration on the Quality and Shelf Life of Frozen Rohu (Labeo rohita) Fillets
}

Faria Afrin' ${ }^{1}$, Md. Golam Rasul' ${ }^{1}$, Murshida Khan ${ }^{1}$, Taslima Akter ${ }^{2}$, Chunhong Yuan ${ }^{3}$, and A.K.M. Azad Shah ${ }^{1, *}$

OPEN ACCESS

${ }^{1}$ Department of Fisheries Technology, Faculty of Fisheries, Bangabandhu Sheikh Mujibur Rahman Agricultural University, Gazipur 1706, Bangladesh,

2 Department of Aquaculture, Faculty of Fisheries, Bangabandhu Sheikh Mujibur Rahman Agricultural University, Gazipur 1706, Bangladesh,

3 Department of Food Production and Environmental Management, Faculty of Agriculture, I wate University, Ueda 3-18-8, Morioka, I wate 020-8550, J apan

*Corresponding Author: azad@bsmrau.edu.bd

Received: 22 September 2020

Accepted: 8 March 2021

Published: 24 May 2021

-Squalen Bulletin of Marine and Fisheries Postharvest and Biotechnology, 2021. Accreditation Number: 148/M/KPT/2020. ISSN: 2089-5690, e-ISSN: 2406-9272. doi: $10.15578 /$ squalen. 504

\begin{abstract}
A natural product such as chitosan promotes health benefits and extends the shelf life of the processed products. Chitosan has been used as a food additive due to its antioxidant and antimicrobial activities. This study was conducted to optimize the chitosan concentration as a coating agent on the quality and shelf life of Labeo rohita fillets during frozen storage. Chitosan $(\mathrm{CH})$ solutions were prepared with $0.5 \%, 1 \%$, and $2 \%(\mathrm{w} / \mathrm{v}) \mathrm{CH}$ in $1 \%(\mathrm{v} / \mathrm{v})$ glacial acetic acid for coating application. The control $(0 \% \mathrm{CH})$ and $\mathrm{CH}$ treated fish fillets were stored at $-18{ }^{\circ} \mathrm{C}$ for 14 weeks and assessed for chemical $(\mathrm{pH}$, thiobarbituric acid reactive substances (TBARS), total volatile basic nitrogen (TVB-N), and $K$-value), microbiological (aerobic plate count (APC)), and sensory properties. The $\mathrm{pH}$, TBARS, and $K$-value of $1 \%$ and $2 \% \mathrm{CH}$ treated fish fillets were acceptable up to $14^{\text {th }}$ week of storage, while TVB-N value was permissible up to $12^{\text {th }}$ week of storage. After $14^{\text {th }}$ week of storage, the APC of control, $0.5 \%, 1 \%$, and $2 \% \mathrm{CH}$ treated fillets were $7.18 \log$ CFU/g, $5.02 \log$ CFU/g, $4.13 \log$ CFU/g, and $3.21 \log$ $\mathrm{CFU} / \mathrm{g}$, respectively. The fish fillets treated with $1 \%$ and $2 \% \mathrm{CH}$ had acceptable sensory attributes up to $12^{\text {th }}$ week, while control fillets were unacceptable after the $6^{\text {th }}$ week of storage. This study demonstrated that $1 \% \mathrm{CH}$ could be used as a natural additive for keeping the quality and extending the shelf life of $L$. rohita fillets during frozen storage.
\end{abstract}

Keywords: Labeo rohita, chitosan, frozen storage, quality, shelf life

\section{I ntroduction}

Indian major carp is one of the most extensively cultured fish due to its fast growth rate, easy cultivation method, and higher market price. Among Indian major carps, Labeo rohita (locally known as Rohu) is the utmost demandable species in Bangladesh due to its palatability and high nutritional value of its flesh. In 2018-2019, the total fish production of Bangladesh was 43,84,221 metric tons; among this, L. rohita production was 2,50,046 metric tons (DoF, 2019). $L$. rohita belongs to the family of Cyprinidae and generally found in the rivers and freshwater lakes of Bangladesh. L. rohita is rich in various nutrients such as protein, polyunsaturated fatty acids, vitamins, and retinol (Jannaty et al., 2020). Therefore, the fish is well accepted as healthy food to the nutritionists and consumers (Doré, 2008). Conversely, fish are recognized as highly perishable food items because of many inherent elements such as neutral $\mathrm{pH}$, low connective tissue, high water-holding capacity, muscle enzymes, and natural microbial flora (Kilincceker, Dogan, \& Kucukoner, 2009).

Various preservation methods prevent chemical deterioration and delay the microbial growth in fish, including $L$. rohita. Frozen storage is the most widely used long-term preservation method, but it does not completely prevent the microbial and chemical reactions that lead to fish spoilage. Moreover, longterm frozen storage causes discoloration and destruction of texture due to protein denaturation and lipid oxidation (Sriket \& La-ongnual, 2018). However, lowering the temperature of fish and chemical preservatives such as BHA and BHT are renowned (Kumar, Yadav, Ahmad, \& Narsaiah, 2015). Due to the potential health risks on the utilization of synthetic preservative agents, various natural additives having antioxidant and antimicrobial activities have been tested as safe replacements to chemical preservatives for fish preservation (Maqsood, Benjakul, \& Shahidi, 2013). 
Natural additives, especially chitosan, have been commonly used for their excellent preservative effect (Duan et al., 2019). Chitosan (poly [ $\beta-(1 \rightarrow 4)$-2-amino2 -deoxy-D-glucopyranose]) is extracted from crustacean shells that have been widely used as a food preservative for its antimicrobial and anti-oxidative activities, biodegradability, biocompatibility, and nontoxicity (Kumar, 2000). Moreover, chitosan has been widely used to extend shelf life, quality, and sensory characteristics in many seafood products (Cao, Xue, \& Liu, 2009; Cai et al., 2014). It has been reported that $2 \%(\mathrm{w} / \mathrm{v})$ chitosan film retains the good quality characteristics and extends the shelf life of frozen silver carp (Fan et al., 2009), while 1.5\% (w/v) edible chitosan coating improves the quality of frozen common carp fillet (Morachis-Valdez et al., 2017). Besides, $1 \%(\mathrm{w} / \mathrm{v})$ chitosan glazing increases shelf life and quality of frozen skinless salmon (Oncorhynchus gorbuscha) fillets (Sathivel, Liu, Huang, \& Prinyawiwatkul, 2007). Moreover, chitosan combined with various natural extracts has also shown synergistic effects on enhancing the quality and shelf life of fish or fishery products during refrigerated storage (Ojagh, Rezaei, Razavi, \& Hosseini, 2010; Li, Li, Hu, \& Li, 2013; Wenjiao, Yongkui, Pan, \& Yuwen, 2013; Hassanzadeh, Moradi, Vaezi, Moosavy, \& Mahmoudi, 2018). However, no studies have been conducted yet about the optimum concentration of chitosan for $L$. rohita preservation. Therefore, this study aimed to optimize the concentration of chitosan as a coating agent to enhance the quality and extend the shelf life of $L$. rohita fillets during frozen storage.

\section{Materials and Methods}

\section{Materials and Chemicals}

Live Rohu (Labeo rohita) (average weight 1,500 \pm $200 \mathrm{~g}$ ) were obtained from a local fish farm (Kapasia, Gazipur district, Bangladesh) and slaughtered by immersion in ice-cold water (hypothermia). Whole $L$. rohita was immediately iced (prepared from freshwater) in an insulated icebox and brought to the Fish Processing Laboratory of the Faculty of Fisheries at Bangabandhu Sheikh Mujibur Rahman Agricultural University. The fish-to-ice ratio was maintained at approximately $1: 2(\mathrm{w} / \mathrm{v})$. Chitosan was procured from Sigma-Aldrich (Saint Louis, MO, USA) company and the degree of deacetylation was $85 \%$. All other chemicals used were of analytical or HPLC grade and were purchased from Wako Pure Chemical Industries Ltd. (Osaka, Japan).

\section{Preparation of Chitosan Solution}

To prepare $0.5 \%, 1.0 \%$, and $2.0 \%(\mathrm{w} / \mathrm{v})$ chitosan solution in $1 \%(\mathrm{v} / \mathrm{v})$ glacial acetic acid, the required amount of chitosan powder was mixed with $900 \mathrm{~mL}$ of distilled water and agitated for $10 \mathrm{~min}$. Furthermore, $10 \mathrm{~mL}$ of glacial acetic acid was added to the solution. The mixture was stirred for $2 \mathrm{~h}$ at room temperature $\left(28 \pm 2{ }^{\circ} \mathrm{C}\right)$, and distilled water was added to the solution to make the final volume of $1,000 \mathrm{~mL}$.

\section{Coating Application and Storage}

Fish were gutted, washed, and filleted manually using sterilized knives and cutting boards. Each fillet was cut into small pieces, and the average weight was $48.2 \pm 12.6 \mathrm{~g}$. The fillets were arbitrarily assigned into four treatments i.e., control (distilled water or $0 \%$ chitosan), $0.5 \% \mathrm{CH}(0.5 \%$ chitosan solution), $1 \% \mathrm{CH}$ ( $1 \%$ chitosan solution) and $2 \% \mathrm{CH}(2 \%$ chitosan solution), each having three replicates. The control treatment fillets were dipped in distilled water, while other treatments were dipped in chitosan solution as described above. The duration of dipping treatment was $10 \mathrm{~min}$ at $4{ }^{\circ} \mathrm{C}$. The fillets were air-dried at room temperature for $5 \mathrm{~min}$ to form an edible coating. All the treated fillets were individually packed in polyethylene freezer bags and stored for 14 weeks at $18{ }^{\circ} \mathrm{C}$ to mimic household freezer conditions. During storage, samples were taken randomly from each treatment every two weeks for chemical, microbiological and sensory evaluations.

\section{Chemical Analyses}

\section{Proximate Composition Analysis}

The proximate composition (moisture, crude protein, and ash) of fish fillets was measured based on the AOAC (2006) methods. The amount of total lipid was determined following the method of Bligh and Dyer (1959).

\section{Determination of $\mathrm{pH}$}

To determine the $\mathrm{pH}$ value, $10 \mathrm{~g}$ of fish sample was homogenized with 10 volumes of distilled water (w/ v), and the homogenate was filtered through Whatman No. 1 filter paper. Hereafter, the $\mathrm{pH}$ was directly measured using a pH meter (MeterLab PHM 310, China).

\section{Determination of Thiobarbituric Acid Reactive Substances (TBARS)}

The TBARS value was estimated following the method of Porkony and Dieffenbancher as described by Kirk and Sawyer (1991). Briefly, $200 \mathrm{mg}$ of fish flesh was weighed into a volumetric flask $(25 \mathrm{~mL})$, and then $1 \mathrm{~mL}$ of 1-butanol was added, then mixed and made to the volume of $25 \mathrm{~mL}$. Five $\mathrm{mL}$ of the 
mixture was transferred into a test tube, and $5 \mathrm{~mL}$ thiobarbituric acid (TBA) reagent was added. The solutions were vortexed, stoppered, and incubated in a water bath at $95{ }^{\circ} \mathrm{C}$ for $120 \mathrm{~min}$, then cooled. The solution was analyzed by reading the absorbance at $530 \mathrm{~nm}$ using a Hitachi U-2000 spectrophotometer (Hitachi Ltd., Tokyo, Japan) at room temperature (28 $\left.\pm 2{ }^{\circ} \mathrm{C}\right)$. The absorbance of the sample $\left(\mathrm{A}_{\mathrm{s}}\right)$ and reagent blank $\left(A_{b}\right)$ was determined. TBARS value $(\mathrm{mg}$ of malonaldehyde equivalent $/ \mathrm{kg}$ of flesh) was measured by the following formula: TBARS $=50 \times\left(\mathrm{A}_{\mathrm{s}}-\mathrm{A}_{\mathrm{b}}\right) / 200$

\section{Determination of Total Volatile Basic Nitrogen (TVB-N)}

The TVB-N value was determined following the method of Goulas and Kontominas (2005). Briefly, the micro-diffusion method was determined by distillation after adding $\mathrm{MgO}$ to the homogenized samples. The TVB-N value was expressed as mg N/100 $\mathrm{g}$ of fish.

\section{Determination of K-value}

For the determination of $K$-value, nucleotides and their related compounds were determined following Yokoyama, Sakaguchi, Kawai, and Kanamori (1992). In brief, $5 \mathrm{~g}$ of fish flesh was homogenized with 25 $\mathrm{mL}$ of cold $10 \%$ perchloric acid (PCA) using an Ace Homogenizer (Nissei AM-72, Nihonseiki Kaisha Ltd., Tokyo, Japan). The homogenate was centrifuged at $11,000 \times g$ for $15 \mathrm{~min}$ at $4{ }^{\circ} \mathrm{C}$. The residue was reextracted twice with $10 \mathrm{~mL}$ of cold $5 \%$ PCA, and the homogenate was centrifuged as before. All supernatants were combined and neutralized with $\mathrm{KOH}$ solution and centrifuged as described above. The supernatant was made up to $100 \mathrm{~mL}$ with de-ionized water, filtered through a $0.20 \mu \mathrm{m}$ polyethylene (PE) membrane filter (Thomas Scientific, NJ, USA), and analyzed by reversed-phase high-performance liquid chromatography (RP-HPLC) (Hitachi 665A, Hitachi Ltd., Tokyo, Japan). A $20 \mu \mathrm{L}$ portion of the filtrate was injected onto an Inertsil C18 column $(5 \mu \mathrm{m} ; 4.6 \mathrm{~mm} \times 250$ $\mathrm{mm}$, GL Science Inc., Tokyo, Japan). The mobile phase consisted of $20 \mathrm{mM}$ citric acid, $20 \mathrm{mM}$ acetic acid, and $40 \mathrm{mM}$ triethylamine, $\mathrm{pH}$ 4.8. The elution was accomplished at a flow rate of $0.6 \mathrm{~mL} / \mathrm{min}$ at $30{ }^{\circ} \mathrm{C}$. The eluting solution was monitored by UV absorbance at $260 \mathrm{~nm}$ at the full scale of 0.02 . The ATP, ADP, AMP, IMP, hypoxanthine, and inosine standards were similarly analyzed by RP-HPLC. To quantify ATPrelated compounds, various amounts of standards were used to prepare calibration curves. $K$-values were calculated by the following formula (Saito, Arai, \& Matsuyoshi, 1959):

$K$-value $(\%)=[(\mathrm{HxR})+(\mathrm{Hx})] /[(\mathrm{ATP})+(\mathrm{ADP})+$ $(\mathrm{AMP})+(\mathrm{IMP})+(\mathrm{HxR})+(\mathrm{Hx})] \times 100 \%$

\section{Microbiological Analysis}

Microbiological analysis was performed following the method described by Maturin and Peeler (2001). In brief, $25 \mathrm{~g}$ of fish sample was taken aseptically into a stomacher bag, and $225 \mathrm{~mL}$ of $0.85 \%$ sterile saline water was added into it. The mixture was then homogenized for $60 \mathrm{~s}$ with a stomacher, and other decimal dilutions were prepared. Aerobic plate count (APC) was determined using plate count agar and incubated at $37^{\circ} \mathrm{C}$ for $24 \mathrm{~h}$. APC was expressed as log colony-forming units per gram or log $\mathrm{CFU} / \mathrm{g}$ of the fish sample.

\section{Sensory Evaluation}

The sensory evaluation of treated fish fillets was performed following Ojagh et al. (2010). Raw fillets (treated and control) were submitted to the panelists and assessed using a 5-point scale. Scoring was done on the basis of texture (value of 5 (firm) to 1 (very soft)); color (value of 5 (no discoloration) to 1 (extreme discoloration)); odor (value of 5 (extremely desirable) to 1 (extremely unacceptable/off-odor)); and overall acceptability (value of 5 (extremely desirable) to 1 (extremely unacceptable)) of the samples. Separated sensory booths were used to perform the sensory evaluation. The panel consisted of seven trained evaluators (ages between 24 and 37 years) from the Department of Fisheries Technology. Shelf life conditions supposed that rejection would occur when the sensory scores were dropped below 4.0 (Fan, Chi, \& Zhang, 2008).

\section{Statistical Analyses}

Statistical analyses were accomplished using the Statistical Analysis System (SAS, 2003, Version 9.1, SAS Institute, Cary, NC, USA). For each parameter, analyses were done in triplicate based on a completely randomized design. Data were subjected to a two-way analysis of variance (ANOVA) followed by a post-hoc test using Duncan's multiple range test to identify the significance of differences among the means at $p<$ 0.05 .

\section{Results and Discussion}

\section{Proximate Composition}

The proximate composition of $L$. rohita fillet was comprised of $81.54 \pm 0.92 \%$ moisture, $15.90 \pm 0.27 \%$ crude protein, $1.27 \pm 0.07 \%$ total lipid, and $1.26 \pm$ $0.06 \%$ ash on a fresh weight basis. It has been reported that the moisture, crude protein, crude lipid, and ash content of farmed and wild L. rohita was 71.68$77.56 \%, 16.62-19.38 \%, 1.30-4.14 \%$, and $0.58-1.23 \%$, 
respectively (Hussain, Mahboob, Hassan, Nadeem, and Sultana, 2011). Hasan, Hossain, and Begum, 2015 also reported that the moisture, crude protein, crude lipid, and an ash content of cultured L. rohita was 73.39$78.09 \%, 16.40-18.55 \%, 6.23-9.03 \%$, and $1.28-2.50 \%$, respectively. The proximate composition of fish varies considerably within the species, fish size, sexual condition, feeding season, and other environmental factors. Moreover, it may affect the taste of the fish, and lead to the processability of fish and fishery products.

\section{pH Values}

The $\mathrm{pH}$ value of fresh $L$. rohita fillet was 6.56 (Figure 1). The $\mathrm{pH}$ values of control, $0.5 \%, 1 \%$, and $2 \% \mathrm{CH}$ treated fillets, were initially decreased to 6.39 , $6.13,6.01$, and 5.89 , respectively, after $2^{\text {nd }}$ week increased significantly $(p<0.05)$ during the storage period. Li et al. (2013) also observed a similar change, who found that the initial decrease and subsequent increase in $\mathrm{pH}$ value during refrigerated storage of Red Drum fillets. After $14^{\text {th }}$ week of storage, the $\mathrm{pH}$ values of control and the fillets treated with $0.5 \%, 1 \%$, and $2 \% \mathrm{CH}$ were $7.12,7.04,6.84$, and 6.78 , respectively. Moreover, there was no significant $(p>0.05)$ difference found in the fillets treated with $1 \%$ and $2 \% \mathrm{CH}$ after the $14^{\text {th }}$ week of storage. The $\mathrm{pH}$ values of chitosan treated fillets were significantly $(p<0.05)$ lowered than that of control, which suggests that chitosan coating might inhibit the microbial growth and extend the shelf life of fish fillets by inhibiting the activity of the endogenous proteases (Fan et al., 2009). At the initial stage, the decreasing of $\mathrm{pH}$ value might be due to lactic acid formation in the fish flesh by glycogen consumption (Cai et al., 2014). Furthermore, the consequent increment of $\mathrm{pH}$ leads to the accumulation of ammonia and trimethylamine caused by endogenous enzyme activity or microbial action (Duman \& Ozpolat,
2015). More similar or less related results were also found by Fan et al. (2009), who observed that the initial decline and gradual increment of $\mathrm{pH}$ values in control and chitosan treated silver carp fillets stored at $-3{ }^{\circ} \mathrm{C}$ for 30 days. In contrast, a steady increase in $\mathrm{pH}$ values observed in beheaded anchovy when stored in chilled conditions (Bensid, Ucar, Bendeddouche, \& Ozogul, 2014).

\section{Thiobarbituric Acid Reactive Substances (TBARS)}

The TBARS value is an indicator of lipid oxidation, measured by the amount of malondialdehyde (MDA). During frozen storage, MDA is produced in fish muscle due to lipid oxidation, which develops toxic substances and unwanted flavors (Wenjiao et al., 2013). The initial TBARS value of $L$. rohita fillets was $0.27 \mathrm{mg}$ MDA/ $\mathrm{kg}$ (Figure 2). After $14^{\text {th }}$ week of storage, the TBARS values of control and the fillets treated with $0.5 \%, 1 \%$, and $2 \% \mathrm{CH}$ were $4.16 \mathrm{mg} \mathrm{MDA} / \mathrm{kg}, 2.21 \mathrm{mg} \mathrm{MDA} /$ $\mathrm{kg}, 1.89 \mathrm{mg} \mathrm{MDA} / \mathrm{kg}$, and $1.78 \mathrm{mg} \mathrm{MDA} / \mathrm{kg}$, respectively. This indicates the control and $0.5 \% \mathrm{CH}$ treated fillets were exceeded the recommended TBARS value (< $2 \mathrm{mg} \mathrm{MDA} / \mathrm{kg}$ for fresh fish) (Connell, 1990). However, no significant difference $(p>0.05)$ was observed in TBARS values between $1 \%$ and $2 \% \mathrm{CH}$ treatments after the $14^{\text {th }}$ week of storage. These results suggested that the application of chitosan progressively retarded the MDA formation. Chitosan coating also retarded MDA formation in frozen $\left(-5^{\circ} \mathrm{C}\right)$ salmon fillets during storage (Soares, Mendes, \& Vicente, 2013). It has been reported that $1 \%$ chitosan coating effectively reduces lipid oxidation in salmon fillets when stored at - $35^{\circ} \mathrm{C}$ for eight months (Sathivel et al., 2007). In our study, it has been noticed that $1 \% \mathrm{CH}$ was easily soluble in the solution and uniformly coated on the fillets as compared with $2 \% \mathrm{CH}$ solution. This might be due to the $2 \% \mathrm{CH}$ solution was thicker than the $1 \% \mathrm{CH}$ solution. Kamil, Jeon, and Shahidi (2002) found that

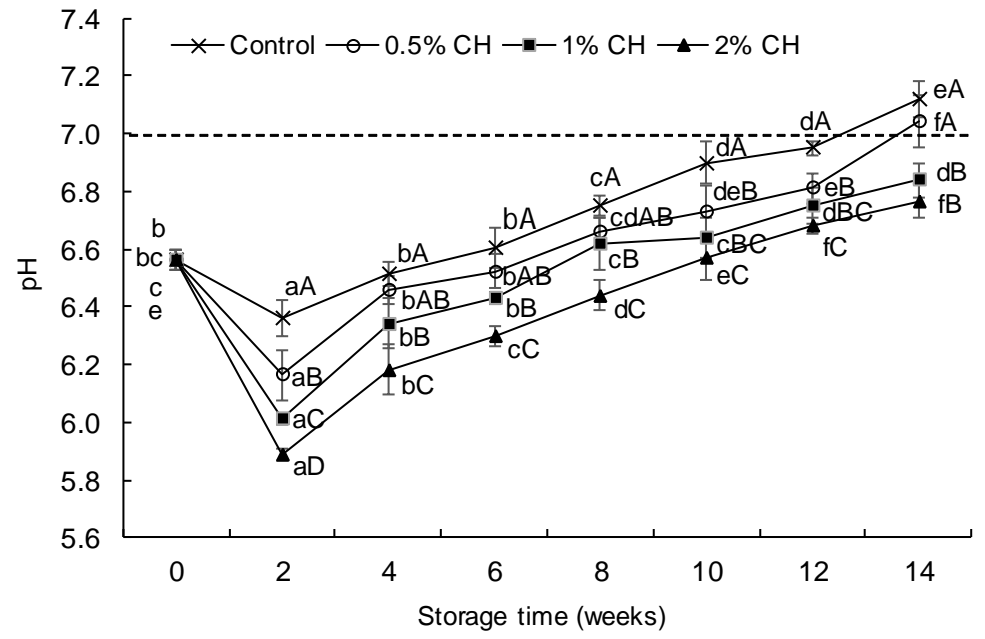

Figure 1. Changes in $\mathrm{pH}$ values of $L$. rohita fillets during frozen storage.

Note:

${ }^{\text {a-f }}$ Lowercase letters in each line indicate significant $(p<0.05)$ differences of means within the storage time; ${ }^{A-D}$ Capital letters indicate significant $(p<0.05)$ differences of means within the treatments; The dotted line indicates the acceptable limit of $\mathrm{pH}$ value (7.0) for fresh fish (Huss, 1998); The error bars represent means \pm SD of triplicates. 


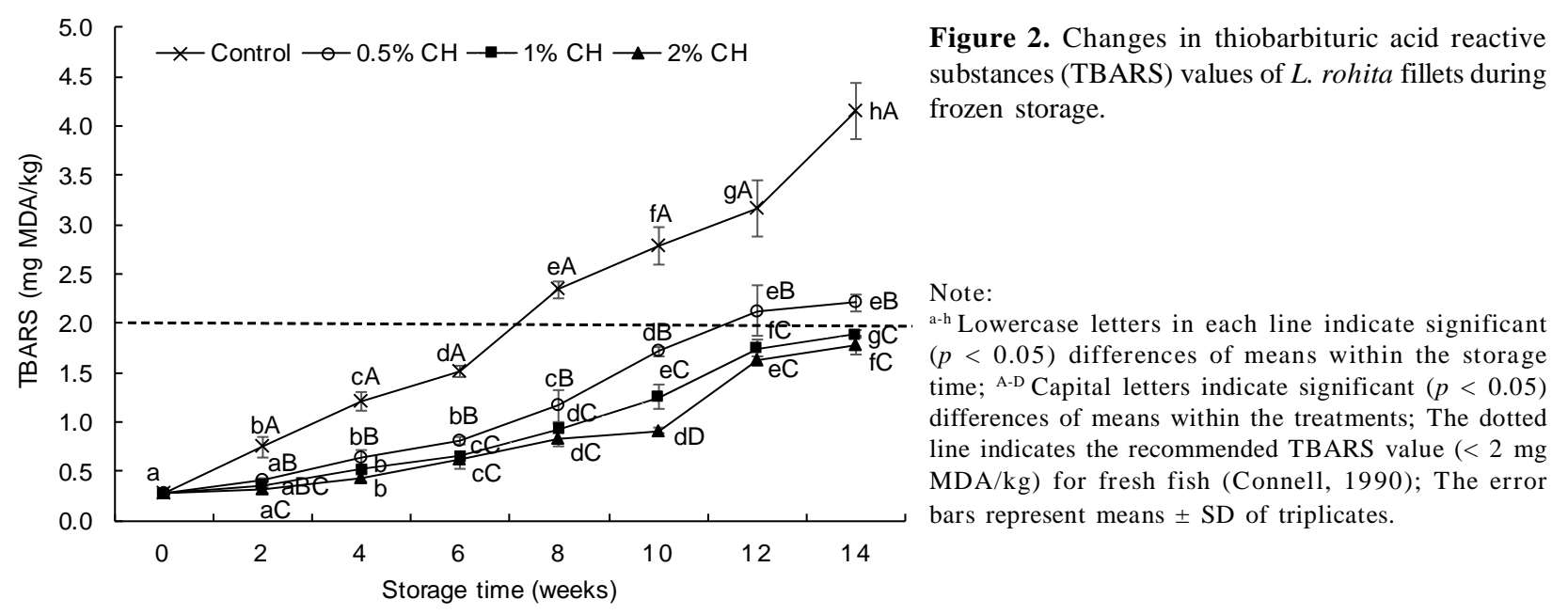

the ferrous ion chelating ability of chitosan inhibits lipid oxidation in fish muscle. Moreover, chitosan coating acts as an obstacle against the penetration of dioxygen on the fish body that inhibits oxidation of lipid in fish muscle (Sathivel, 2005; Ojagh et al., 2010).

\section{Total Volatile Basic Nitrogen (TVB-N)}

The TVB-N is often used as an indicator of fish spoilage, mainly composed of nitrogenous substances produced from the bacterial proteolytic action and endogenous enzyme activity (Kilincceker et al., 2009). The initial TVB-N value of $L$. rohita fillet was $7.53 \mathrm{mg}$ N/100 g (Figure 3). The TVB-N value of control and chitosan treated fillets were increased noticeably $(p<$ $0.05)$ with the increase of storage time. After $4^{\text {th }}$ week of storage, the TVB-N value of control, $0.5 \%, 1 \%$, and $2 \% \mathrm{CH}$ treated fillets were $24.01 \mathrm{mg} \mathrm{N} / 100 \mathrm{~g}$, $22.55 \mathrm{mg} \mathrm{N} / 100 \mathrm{~g}, 20.33 \mathrm{mg} \mathrm{N} / 100 \mathrm{~g}$, and $18.27 \mathrm{mg}$ $\mathrm{N} / 100 \mathrm{~g}$, respectively, which suggest that all the values were within an acceptable range $(<25 \mathrm{mg} \mathrm{N} / 100 \mathrm{~g})$ (Giménez, Roncalés, \& Beltrán, 2002). The TVB-N value of control and $0.5 \% \mathrm{CH}$ treated fillets were

exceeded the acceptable limit after the $4^{\text {th }}$ and $6^{\text {th }}$ weeks of storage, respectively, while the fillets treated with $1 \%$ and $2 \% \mathrm{CH}$ exceeded the allowable limit after the $12^{\text {th }}$ week of storage. However, no significant $(p>0.05)$ variation was observed in TVB-N values between $1 \%$ and $2 \% \mathrm{CH}$ treated fillets during frozen storage. Moreover, chitosan-treated fillets showed comparatively lower TVB-N values that might be resulted in either reduced bacterial population or decreased bacterial activity for oxidative de-amination of non-protein nitrogenous substances or both (Ojagh et al., 2010). It has been reported that chitosan coating efficiently reduced the TVB-N values in silver carp when stored at $-3{ }^{\circ} \mathrm{C}$ for 30 days (Fan et al., 2008). Mi et al. (2017) also found that chitosan combined with 6-gingerol significantly delay the increment of TVB-N values in red drum fillets during refrigerated storage.

\section{K-value}

$K$-value is the index of ATP deprivation, therefore mainly used as a freshness indicator of fish. ATP is

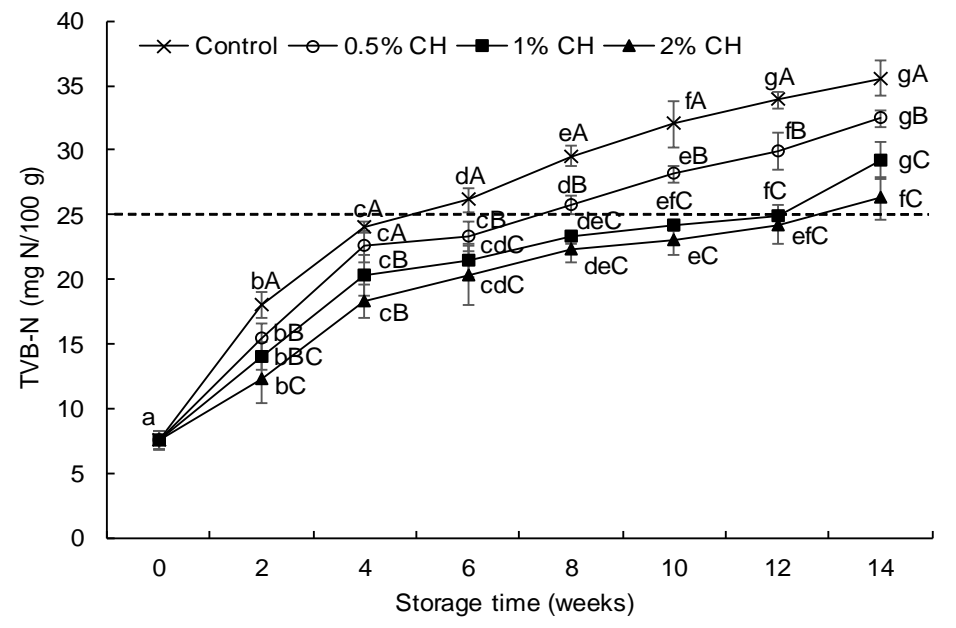

Figure 3. Changes in total volatile basic-nitrogen (TVB-N) values of L. rohita fillets during frozen storage.

Note:

${ }^{a-g}$ Lowercase letters in each line indicate significant $(p<0.05)$ differences of means within the storage time; A-C Capital letters indicate significant $(p<0.05)$ differences of means within the treatments; The dotted line indicates an acceptable range of TVB-N value $(<25$ $\mathrm{mg} \mathrm{N} / 100 \mathrm{~g}$ of fresh fish) (Giménez et al., 2002); The error bars represent means \pm SD of triplicates. 


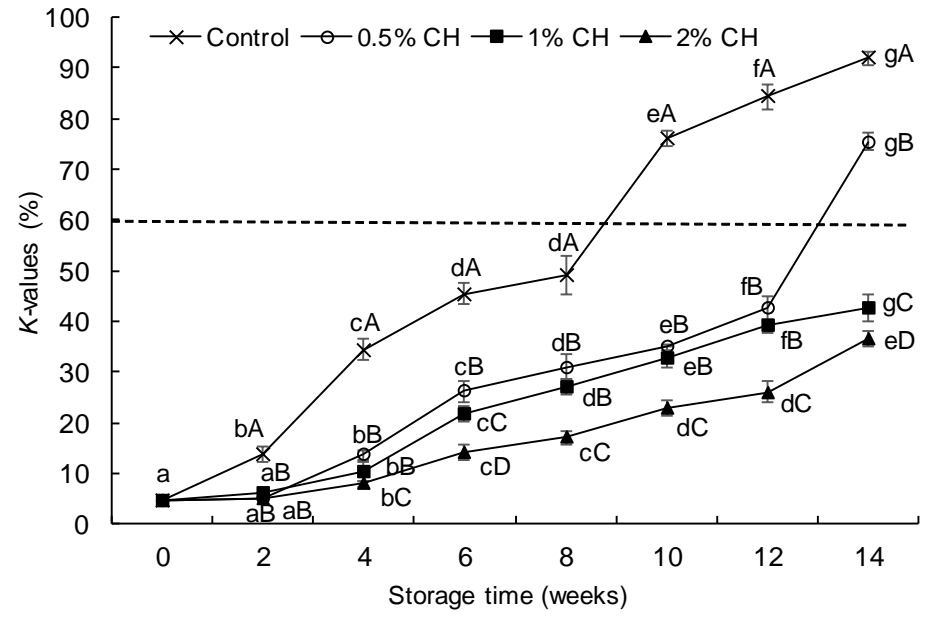

Figure 4. Changes in $K$-values of $L$. rohita fillets during frozen storage. breakdown by endogenous enzymes of fish in the early stage of storage, which is found equivalent to the loss of freshness of fish. The initial $K$-value of $L$. rohita fillet was $4.45 \%$ (Figure 4). In general, the initial $K$ value of post-capture fish is less than $10 \%$ that might be the degradation of endogenous proteases, and further increment of $K$-value mainly due to the bacterial activities (Liu et al., 2010). After $14^{\text {th }}$ week of storage, the $K$-values of control and the fillets treated with $0.5 \%$, $1 \%$, and $2 \% \mathrm{CH}$ were $91.96 \%, 75.42 \%, 42.64 \%$, and $36.59 \%$ respectively. This indicated that chitosan effectively inhibits the degradation of ATP and possibly extended the shelf life of fish fillets. The $K$-values of control and $0.5 \% \mathrm{CH}$ treated fillets were exceeded the recommended limit after the $8^{\text {th }}$ and $12^{\text {th }}$ weeks of storage, respectively. Ehira (1976) reported that the rejection threshold of $\leq K$-value in fish is $60 \%$. In contrast, $K$-values of $1 \%$ and $2 \% \mathrm{CH}$ treated fillets were within the acceptable range during the storage time. However, a significant $(p<0.05)$ variation was observed in the $K$-values during the frozen storage. Moreover, chitosan treated fish fillets showed comparatively lower $K$-values than control, which might be the ability of chitosan to minimize the 5nucleotidase activity and thus retarding the breakdown rate of IMP (Aubourg, Pineiro, Gallardo, \& BarrosVelazquez, 2005; Nejib, Moza Abdallah, Ismail Mohammed, Ann, \& Mohammad, 2005; Fan et al., 2009).

\section{Microbial Analysis}

The initial APC of fresh L. rohita fillet was 2.89 $\log \mathrm{CFU} / g$ (Figure 5). After two weeks of storage, the APC of the untreated fillet (control) was increased from $2.89 \log \mathrm{CFU} / \mathrm{g}$ to $3.14 \log \mathrm{CFU} / \mathrm{g}$, while it was decreased in the chitosan-coated fillets. However, no bacteria were found in the fish fillets preserved with $1 \%$ and $2 \% \mathrm{CH}$ during the $2^{\text {nd }}$ to $6^{\text {th }}$ week of storage. It suggests that chitosan effectively inhibit the microbial growth (Lopez-Caballero, Gómez-Guillén, Pérez Mateos, \& Montero, 2005; Fernandez-Saiz, Soler, Lagaron, \& Ocio, 2010). Moreover, chitosan coating acts as an oxygen barrier, which retards aerobic bacterial growth (Devlieghere, Vermeulen, \& Debevere, 2004). The antimicrobial action of chitosan can be mediated by the interactions between the positively

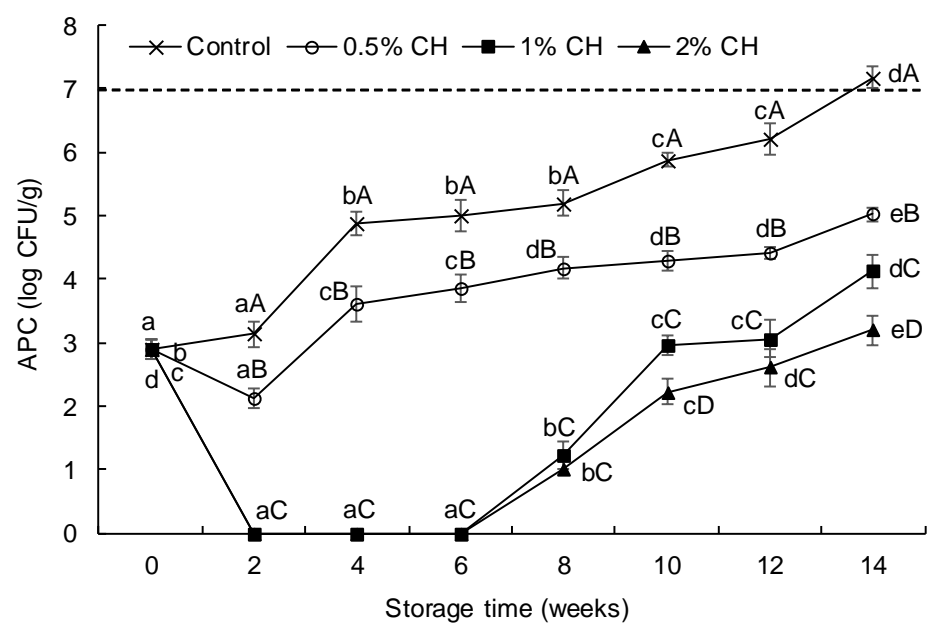

Figure 5. Changes in aerobic plate count (APC) values of $L$. rohita fillets during frozen storage.

Note:

${ }^{a-e}$ Lowercase letters in each line indicate significant $(p<0.05)$ differences of means within the storage time; A-D Capital letters indicate significant $(p<0.05)$ differences of means within the treatments; The dotted line indicates the acceptable bacteriological limit of $7 \mathrm{log}$ CFU/g for raw fish (Ojagh et al., 2010); The error bars represent means \pm SD of triplicates. 
charged chitosan and negatively charged microbial cell membranes, which induces the leakage of cellular proteins and other intracellular constituents (No, Meyers, Prinyawiwatkul, \& Xu, 2007). In contrast, the untreated fillet attained an APC value of $7.18 \mathrm{log}$ CFU/g after 12 weeks of storage, which exceeded the allowable bacteriological limit of $7 \log \mathrm{CFU} / \mathrm{g}$ for raw fish (Ojagh et al., 2010). At the end of $14^{\text {th }}$ week of frozen storage, the APC of control and the fillets treated with $0.5 \%, 1 \%$, and $2 \% \mathrm{CH}$ were $7.18 \mathrm{log} \mathrm{CFU} / \mathrm{g}$, $5.02 \log \mathrm{CFU} / \mathrm{g}, 4.13 \log \mathrm{CFU} / \mathrm{g}$, and $3.21 \log \mathrm{CFU} / \mathrm{g}$, respectively, which suggests that chitosan coating markedly decreased bacterial activity. However, there was no significant $(p>0.05)$ variation found in APC between $1 \%$ and $2 \% \mathrm{CH}$ treated fillets throughout the storage period. Similar results were also found in salmon (Vásconez, Flores, Campos, Alvarado, \& Gerschenson, 2009), silver carp (Fan et al., 2009), lingcod (Duan, Cherian, \& Zhao, 2010), cod (GómezEstaca, López de Lacey, López-Caballero, GómezGuillén, \& Montero, 2010) and rainbow trout (Ojagh et al., 2010), where chitosan significantly reduce or inhibit the microbial growth as well as improve the quality of the products.

\section{Sensory Evaluation}

The changes in sensory characteristics of $L$. rohita fillets during frozen storage are depicted in Table 1. All the sensory attributes of control and $0.5 \% \mathrm{CH}$ treated fillets were found unacceptable scores by the $8^{\text {th }}$ and $10^{\text {th }}$ weeks, respectively, while fillets treated with $1 \%$ and $2 \% \mathrm{CH}$ were found permissible (above 4.0) up to $12^{\text {th }}$ weeks of storage. After $12^{\text {th }}$ week of storage, no significant difference $(p>0.05)$ was found in the sensory characteristics between $1 \%$ and $2 \% \mathrm{CH}$ treated fillets. The results of sensory evaluation supported the chemical and microbial data of this study. The untreated fillets were found to be spoiled after the $8^{\text {th }}$ week of storage because of the higher degree of lipid oxidation as well as bacterial growth. Duan et al. (2010) reported that chitosan coating had been shown to reduce the oxidative effects and extend the shelf life of fishery products. Moreover, chitosan coating positively influences the sensory attributes of fish fillets that ultimately enhance the quality and shelf life of fish during frozen storage (Ojagh et al., 2010).

\section{Conclusion}

The results of this study suggest that chitosan coating was effective in keeping the quality and improving the shelf life of $L$. rohita fillets during frozen storage based on chemical, microbiological and sensory properties. The $\mathrm{pH}$ value of fish fillet was initially decreased, then it was increased during storage. In contrast, TBARS, TVB-N, and $K$-value of the fish fillets were increased significantly $(p<0.05)$ throughout the

Table 1. Changes in sensory characteristics of $L$. rohita fillets during frozen storage ${ }^{1}$

\begin{tabular}{|c|c|c|c|c|c|c|c|c|c|}
\hline \multirow{2}{*}{$\begin{array}{l}\text { Sens ory } \\
\text { attributes }\end{array}$} & \multirow{2}{*}{ Treatments } & \multicolumn{8}{|c|}{ Sto rage time (weeks) } \\
\hline & & 0 & 2 & 4 & 6 & 8 & 10 & 12 & 14 \\
\hline \multirow[t]{4}{*}{ Texture } & Control & $5.00 \pm 0.00_{\mathrm{a}}^{\mathrm{a}}$ & $4.47 \pm 0.26_{\mathrm{a}}^{\mathrm{b}}$ & $4.11 \pm 0.39_{\mathrm{a}}^{\mathrm{c}}$ & $4.09 \pm 0.33_{\mathrm{a}}^{\mathrm{c}}$ & $3.43 \pm 0.29 \mathrm{a}^{\mathrm{d}}$ & $1.52 \pm 0.51_{a}^{e}$ & $1.26 \pm 0.17_{\mathrm{a}}^{\mathrm{e}}$ & $1.21 \pm 0.20_{\mathrm{a}}^{\mathrm{e}}$ \\
\hline & $0.5 \% \mathrm{CH}$ & $5.00 \pm 0.00 \mathrm{a}^{\mathrm{a}}$ & $4.75 \pm 0.10_{\mathrm{b}}^{\mathrm{ab}}$ & $4.58 \pm 0.17_{\mathrm{b}}^{\mathrm{b}}$ & $4.24 \pm 0.27 \mathrm{a}^{\mathrm{c}}$ & $4.32 \pm 0.37_{\mathrm{b}}^{\mathrm{c}}$ & $3.93 \pm 0.28_{b}{ }^{\mathrm{cd}}$ & $3.84 \pm 0.17_{\mathrm{b}}^{\mathrm{de}}$ & $3.77 \pm 0.18_{\mathrm{b}}^{\mathrm{e}}$ \\
\hline & $1 \% \mathrm{CH}$ & $5.00 \pm 0.00_{\mathrm{a}^{\mathrm{a}}}$ & $4.89 \pm 0.28_{\mathrm{b}}^{\mathrm{ab}}$ & $4.80 \pm 0.40_{\mathrm{b}}^{\mathrm{ab}}$ & $4.73 \pm 0.39_{\mathrm{b}}^{\mathrm{abc}}$ & $4.62 \pm 0.37 \mathrm{~b}$ & $4.42 \pm 0.32_{\mathrm{b}}^{\mathrm{cd}}$ & $4.15 \pm 0.26_{c}{ }^{d}$ & $3.86 \pm 0.36_{c}{ }^{d}$ \\
\hline & $2 \% \mathrm{CH}$ & $5.00 \pm 0.00_{\mathrm{a}^{\mathrm{a}}}$ & $4.86 \pm 0.13_{\mathrm{b}}^{\mathrm{ab}}$ & $4.91 \pm 0.23_{\mathrm{b}}^{\mathrm{ab}}$ & $4.83 \pm 0.26_{\mathrm{b}}^{\mathrm{ab}}$ & $4.75 \pm 0.42_{\mathrm{b}}^{\mathrm{ab}}$ & $4.74 \pm 0.39{ }_{c}^{a b}$ & $4.34 \pm 0.37 \mathrm{c}_{\mathrm{c}}^{\mathrm{b}}$ & $4.13 \pm 0.26_{c}{ }^{b}$ \\
\hline \multirow[t]{4}{*}{ Color } & Control & $5.00 \pm 0.00_{\mathrm{a}}^{\mathrm{a}}$ & $4.53 \pm 0.12_{\mathrm{a}}^{\mathrm{b}}$ & $4.34 \pm 0.52_{\mathrm{a}}^{\mathrm{bc}}$ & $4.14 \pm 0.14_{\mathrm{a}}^{\mathrm{c}}$ & $3.10 \pm 0.11_{\mathrm{a}}^{\mathrm{d}}$ & $2.16 \pm 0.14_{\mathrm{a}}^{\mathrm{e}}$ & $1.28 \pm 0.25_{\mathrm{a}}{ }^{\mathrm{f}}$ & $1.21 \pm 0.22_{\mathrm{a}}^{\mathrm{f}}$ \\
\hline & $0.5 \% \mathrm{CH}$ & $5.00 \pm 0.00_{\mathrm{a}^{\mathrm{a}}}$ & $4.84 \pm 0.17_{\mathrm{b}}^{\mathrm{ab}}$ & $4.64 \pm 0.22_{\mathrm{a}}^{\mathrm{bb}}$ & $4.32 \pm 0.19_{\mathrm{a}}^{\mathrm{c}}$ & $4.56 \pm 0.2 \mathrm{l}_{\mathrm{b}}^{\mathrm{b}}$ & $3.87 \pm 0.12_{b}{ }^{d}$ & $3.70 \pm 0.27_{b}{ }^{d}$ & $3.73 \pm 0.15_{c}^{d}$ \\
\hline & $1 \% \mathrm{CH}$ & $5.00 \pm 0.00_{\mathrm{a}^{\mathrm{a}}}$ & $4.91 \pm 0.18_{\mathrm{b}}{ }^{\mathrm{a}}$ & $4.89 \pm 0.22^{\mathrm{b}}$ & $4.81 \pm 0.17_{\mathrm{b}}^{\mathrm{a}}$ & $4.70 \pm 0.27_{\mathrm{b}}^{\mathrm{a}}$ & $4.42 \pm 0.54_{\mathrm{b}}^{\mathrm{cb}}$ & $4.14 \pm 0.37 \mathrm{c}^{\mathrm{c}}$ & $3.78 \pm 0.21_{\mathrm{b}}^{\mathrm{c}}$ \\
\hline & $2 \% \mathrm{CH}$ & $5.00 \pm 0.00_{\mathrm{a}}^{\mathrm{a}}$ & $4.93 \pm 0.18_{\mathrm{b}}{ }^{\mathrm{a}}$ & $4.89 \pm 0.27_{\mathrm{b}}^{\mathrm{a}}$ & $4.76 \pm 0.38_{\mathrm{b}}^{\mathrm{ab}}$ & $4.70 \pm 0.47_{\mathrm{b}}^{\mathrm{ab}}$ & $4.67 \pm 0.52_{\mathrm{c}^{\mathrm{ab}}}$ & $4.46 \pm 0.45_{\mathrm{c}}^{\mathrm{b}}$ & $3.94 \pm 0.30_{\mathrm{b}}^{\mathrm{b}}$ \\
\hline \multirow[t]{4}{*}{ Odor } & Control & $5.00 \pm 0.00_{\mathrm{a}^{\mathrm{a}}}$ & $4.49 \pm 0.19_{\mathrm{a}}^{\mathrm{b}}$ & $4.13 \pm 0.15_{\mathrm{a}}^{\mathrm{c}}$ & $3.38 \pm 0.18_{\mathrm{a}}^{\mathrm{d}}$ & $3.16 \pm 0.27 \mathrm{a}_{\mathrm{a}}^{\mathrm{e}}$ & $2.41 \pm 0.11_{\mathrm{a}}^{\mathrm{f}}$ & $1.38 \pm 0.13_{\mathrm{a}^{\mathrm{g}}}^{\mathrm{g}}$ & $1.07 \pm 0.12_{\mathrm{a}}{ }^{\mathrm{h}}$ \\
\hline & $0.5 \% \mathrm{CH}$ & $5.00 \pm 0.00_{\mathrm{a}^{a}}$ & $4.86 \pm 0.16_{\mathrm{b}}^{\mathrm{ab}}$ & $4.76 \pm 0.19_{\mathrm{b}}^{\mathrm{b}}$ & $4.29 \pm 0.17_{\mathrm{b}}^{\mathrm{c}}$ & $4.12 \pm 0.10_{\mathrm{b}}{ }^{\mathrm{c}}$ & $3.97 \pm 0.16_{\mathrm{b}}^{\mathrm{c}}$ & $3.63 \pm 0.36_{b}{ }^{d}$ & $3.68 \pm 0.24_{b}{ }^{d}$ \\
\hline & $1 \% \mathrm{CH}$ & $5.00 \pm 0.00_{\mathrm{a}^{\mathrm{a}}}$ & $4.93 \pm 0.18_{\mathrm{b}}{ }^{\mathrm{a}}$ & $4.77 \pm 0.31_{b}{ }^{a}$ & $4.83 \pm 0.18_{\mathrm{c}}{ }^{\mathrm{a}}$ & $4.69 \pm 0.35_{\mathrm{c}}{ }^{\mathrm{a}}$ & $4.29 \pm 0.36_{c}{ }^{b}$ & $4.15 \pm 0.22_{\mathrm{c}}^{\mathrm{b}}$ & $3.93 \pm 0.29_{c}{ }^{b}$ \\
\hline & $2 \% \mathrm{CH}$ & $5.00 \pm 0.00_{\mathrm{a}}^{\mathrm{a}}$ & $4.81 \pm 0.33_{\mathrm{b}}{ }^{\mathrm{a}}$ & $4.86 \pm 0.22_{\mathrm{b}}^{\mathrm{a}}$ & $4.76 \pm 0.28_{\mathrm{c}}{ }^{\mathrm{a}}$ & $4.81 \pm 0.40_{\mathrm{c}^{\mathrm{a}}}$ & $4.67 \pm 0.37_{\mathrm{c}}^{\mathrm{ab}}$ & $4.34 \pm 0.37 \mathrm{c}^{\mathrm{b}}$ & $4.04 \pm 0.36_{\mathrm{c}}^{\mathrm{b}}$ \\
\hline \multirow[t]{4}{*}{ Overall } & Control & $5.00 \pm 0.00_{\mathrm{a}}^{\mathrm{a}}$ & $4.61 \pm 0.177_{\mathrm{a}}^{\mathrm{ab}}$ & $4.40 \pm 0.49_{\mathrm{a}}^{\mathrm{bc}}$ & $4.10 \pm 0.14_{\mathrm{a}}^{\mathrm{c}}$ & $3.08 \pm 0.20_{\mathrm{a}}{ }^{\mathrm{d}}$ & $2.67 \pm 0.52_{\mathrm{a}}^{\mathrm{d}}$ & $1.64 \pm 0.89_{\mathrm{a}}{ }^{\mathrm{e}}$ & $1.16 \pm 0.25_{\mathrm{a}}^{\mathrm{e}}$ \\
\hline & $0.5 \% \mathrm{CH}$ & $5.00 \pm 0.00_{\mathrm{a}}^{\mathrm{a}}$ & $4.78 \pm 0.39_{\mathrm{a}}^{\mathrm{ab}}$ & $4.65 \pm 0.34_{\mathrm{aa}}^{\mathrm{bc}}$ & $4.42 \pm 0.36_{\mathrm{ab}}^{\mathrm{bc}}$ & $4.28 \pm 0.36_{b}{ }^{c d}$ & $3.89 \pm 0.2 \mathrm{1}_{\mathrm{b}}^{\mathrm{de}}$ & $3.73 \pm 0.37_{\mathrm{b}}{ }^{e f}$ & $3.39 \pm 0.45_{b}{ }^{\mathrm{f}}$ \\
\hline & $1 \% \mathrm{CH}$ & $5.00 \pm 0.00_{\mathrm{a}^{\mathrm{a}}}$ & $4.87 \pm 0.27_{\mathrm{a}}^{\mathrm{ab}}$ & $4.82 \pm 0.40_{\mathrm{a}}^{\mathrm{ab}}$ & $4.77 \pm 0.41_{\mathrm{b}}^{\mathrm{ab}}$ & $4.64 \pm 0.37_{\mathrm{bc}}^{\mathrm{abc}}$ & $4.52 \pm 0.32_{\mathrm{c}}^{\mathrm{bcd}}$ & $4.22 \pm 0.25_{\mathrm{bc}}^{\mathrm{cd}}$ & $4.32 \pm 0.38_{c}{ }^{d}$ \\
\hline & $2 \% \mathrm{CH}$ & $5.00 \pm 0.00_{\mathrm{a}}^{\mathrm{a}}$ & $4.83 \pm 0.4 \mathrm{1}_{\mathrm{a}}^{\mathrm{ab}}$ & $4.80 \pm 0.39 \mathrm{a}^{\mathrm{ab}}$ & $4.76 \pm 0.38_{\mathrm{b}}^{\mathrm{ab}}$ & $4.68 \pm 0.35_{\mathrm{ca}}^{\mathrm{cc}}$ & $4.62 \pm 0.31_{\mathrm{ca}}^{\mathrm{bc}}$ & $4.53 \pm 0.32_{\mathrm{c}}^{\mathrm{bc}}$ & $4.35 \pm 0.34_{c^{c}}{ }^{c}$ \\
\hline
\end{tabular}

Note:

${ }^{1}$ The values are expressed as mean \pm standard deviation $(\mathrm{n}=7)$;

Subscript letters within the same column indicate significant $(p<0.05)$ differences of means within the treatments; Superscript letters within the same row indicate significant $(p<0.05)$ differences of means within the storage time; The acceptable value of the sensory attribute is above 4.0 for fresh fish (Fan et al., 2008). 
storage period. However, $\mathrm{pH}$, TBARS, and $K$-values of the fillets treated with $1 \%$ and $2 \% \mathrm{CH}$ were within the recommended level up to $14^{\text {th }}$ week of storage, while TVB-N value was acceptable up to 12 weeks of storage. The fish fillets treated with chitosan significantly decreased microbial growth as compared to the control. Sensory evaluation revealed that $1 \%$ and $2 \% \mathrm{CH}$ treated fish fillets were acceptable up to 12 weeks of storage. This study indicated that chitosan coating treatments predominantly reduced the chemical deterioration and retarded bacterial growth, and increased shelf life of $L$. rohita fillets during frozen storage. Thus, it can be concluded that $1 \% \mathrm{CH}$ coating might be a promising technique for preserving L.rohita fillets.

\section{Acknowledgments}

This work was financed by the Ministry of Science and Technology of Bangladesh (No.: 39.00.0000.09. 06.79.2017/BS-82).

\section{References}

AOAC Assn. of Official Analytical Chemists (2006). Official methods of analysis. $18^{\text {th }}$ Ed. Virginia, USA: AOAC International.

Aubourg, S. P., Pineiro, C., Gallardo, J. M., \& Barros-Velazquez, J. (2005). Biochemical changes and quality loss during chilled storage of farmed turbot (Psetta maxima). Food Chemistry, 90, 445-452. doi: 10.1016/j.foodchem. 2004.05.008

Bensid, A., Ucar, Y., Bendeddouche, B., \& Ozogul, F. (2014). Effect of the icing with thyme, oregano, and clove extracts on quality parameters of gutted and beheaded anchovy (Engraulis encrasicholus) during chilled storage. Food Chemistry, 145, 681-686. doi: 10.1016/j.foodchem. 2013.08.106

Bligh, G., \& Dyer, W. J. (1959). A rapid method of total lipid extraction and purification. Canadian Journal of Biochemistry and Physiology, 37, 911-917.

Cai, L. Y., Li, X. P., Wu, X. S., Lv, Y. F., Liu, X. F., \& Li, J. R. (2014). Effect of chitosan coating enriched with ergothioneine on quality changes of Japanese sea bass (Lateolabrax japonicas). Food Bioprocess Technology, 7, 2281-2290. doi: 10.1007/s11947-013-1215-4

Cao, R., Xue, C. H., \& Liu, Q. (2009). Changes in microbial flora of Pacific oysters (Crassostrea gigas) during refrigerated storage and its shelf life extension by chitosan. International Journal of Food Microbiology, 131, 272-276. doi: 10.1016/j.ijfoodmicro.2009.03.004

Connell, J. J. (1990). Control of fish quality, 3rd edn. Fishing News Books, Oxford, 1-227.

Department of Fisheries (DoF) (2019). Yearbook of fisheries statistics of Bangladesh, 2018-19; Fisheries Resources Survey System (FRSS), 36(1-135) DoF: Dhaka, Bangladesh.

Devlieghere, F., Vermeulen, A., \& Debevere, J. (2004). Chitosan: antimicrobial activity, interactions with food components, and applicability as a coating on fruit and vegetables. Food Microbiology, 21(6), 703-714. doi: 10.1016/j.fm.2004.02.008
Doré, B. (2008). Introduction to Part III: ensuring seafood safety. In T. Børresen (Ed.), Improving Seafood Products for the Consumer (pp. 185-193). England, Woodhead Publishing Limited.

Duan, J., Cherian, G., \& Zhao, Y. (2010). Quality enhancement in fresh and frozen lingcod (Ophiodon elongates) fillets by employment of fish oil incorporated chitosan coatings. Food Chemistry, 119(2), 524-532. doi: 10.1016/j.foodchem. 2009.06.055

Duan, C., Meng, X., Meng, J., Khan, M. I. H., .... Ni, Y. (2019). Chitosan as a preservative for fruits and vegetables: a review on chemistry and antimicrobial properties. Journal of Bioresources and Bioproducts, 4, 11-21. doi: 10.21967/ jbb.v4i1.189

Duman, M., \& Ozpolat, E. (2015). Effects of water extract of propolis on fresh shibuta (Barbus grypus) fillets during chilled storage. Food Chemistry, 189, 80-85. doi: 10.1016/ j.foodchem.2014.08.091

Ehira, S. (1976). A biochemical study on the freshness of fish. Bulletin of Tokai Regional Fisheries Research Laboratory, 88, 130-132.

Fan, W., Chi, Y., \& Zhang, S. (2008). The use of a tea polyphenol dip to extend the shelf life of silver carp (Hypophthalmicthys molitrix) during storage in ice. Food Chemistry, 108, 148153. doi: 10.1016/j.foodchem.2007.10.057

Fan, W., Sun, J., Chen, Y., Qiu, J., Zhang, Y., \& Chi, Y. (2009). Effects of chitosan coating on quality and shelf life of silver carp during frozen storage. Food Chemistry, 115(1), 66-70. doi: 10.1016/j.foodchem.2008.11.060

Fernandez-Saiz, P., Soler, C., Lagaron, J. M. \& Ocio, M. J. (2010). Effects of chitosan films on the growth of Listeria monocytogenes, Staphylococcus aureus, and Salmonella spp. in laboratory media and in fish soup. International Journal of Food Microbiology, 137(2-3), 287-94. doi: 10.1016/j. ijfoodmicro.2009.11.016

Giménez, B., Roncalés, P., \& Beltrán, J. A. (2002). Modified atmosphere packaging of filleted rainbow trout. Journal of the Science of Food and Agriculture, 82(10), 1154-1159. doi: $10.1002 /$ jsfa. 1136

Gómez-Estaca, J., López de Lacey, A., López-Caballero, M. E., Gómez-Guillén, M. C. \& Montero, P. (2010). Biodegradable gelatin chitosan films incorporated with essential oils as antimicrobial agents for fish preservation. Food Microbiology, 27(7), 889-896. doi: 10.1016/j.fm. 2010.05.012

Goulas, A. E., \& Kontominas, M. G. (2005). Effect of salting and smoking-method on the keeping quality of chub mackerel (Scomber japonicus): Biochemical and sensory attributes. Food Chemistry, 93(3), 511-520. doi: 10.1016/j.foodchem. 2004.09.040

Hasan, G. M. M. A., Hossain, M. S., \& Begum, M. (2015). Biochemical composition of Rui (Labeo rohita), catla (Catla catla), tilapia (Oreochromis mossambicus) of cultured ponds and different markets of Bangladesh. International Journal for Research in Applied Science \& Engineering Technology, 3(1), 222-226.

Hassanzadeh, P., Moradi, M., Vaezi, N., Moosavy, M. H., \& Mahmoudi, R. (2018). Effects of chitosan edible coating containing grape seed extract on the shelf life of refrigerated rainbow trout fillet. Veterinary Research Forum, 9(1), 7379 . 
Hussain, B., Mahboob, S., Hassan, M., Nadeem, S., \& Sultana, T. (2011). Effect of maturation degree on fatty acid profile of different tissues in wild and farmed Rohu (Labeo rohita). Grasas YAceites, 62(2), 206-212. doi: 10.3989/gya.090510

Huzz, H. H. (1998). Quality and quality changes in fresh fish. FAO Fisheries Technical Paper - 348. Food and Agriculture Organization of the United Nations, Rome, 202 p.

Jannaty, T., Raknuzzaman, M., Masum, A. S. M. H. A., Ara, K. J., Ahmed, M. A., \& Kabir, Y. (2020). Nutrients composition in selected key foods of animal origin of Bangladesh. European Journal of Pharmaceutical and Medical Research, 7(5), 42-51.

Kamil, J. Y. V. A., Jeon, J. J., \& Shahidi, F. (2002). Anti-oxidative activity of chitosans of different viscosity in cooked comminuted flesh of herring (Clupea harengus). Food Chemistry, 79(1), 69-77. doi: 10.1016/S0308-8146(02) 00180-2

Kilincceker O., Dogan, Ý. S., \& Kucukoner, E. (2009) Effect of edible coatings on the quality of frozen fish fillets. LWT Food Science and Technology, 42(4), 868-873. doi: 10.1016/ j.lwt.2008.11.003

Kirk R. S., \& Sawyer, R. (1991). Pearson's composition and analysis of foods (9th ed). UK: Longman Scientific and Technical, Harlow. pp. 640, 643.

Kumar, M. N. V. R. (2000). A review of chitin and chitosan applications. Reactive and Functional Polymers, 46(1), 127. doi: 10.1016/S1381-5148(00)00038-9

Kumar, Y., Yadav, D. N., Ahmad, T., \& Narsaiah, K. (2015). Recent trends in the use of natural antioxidants for meat and meat products. Comprehensive Reviews in Food Science and Food Safety, 14(6), 796-812. doi: 10.1111/1541-4337. 12156

Li, T. T., Li, J. R., Hu, W. Z., \& Li, X. P. (2013). Quality enhancement in refrigerated red drum (Sciaenops ocellatus) fillets using chitosan coatings containing natural preservatives. Food Chemistry, 138(2-3), 821-826. doi: 10.1016/j.foodchem.2012.11.092

Liu, S. C., Fan, W., Zhong, S. Y., Ma, C. W., Li, P. L., \& Zhou, K. (2010). Quality evaluation of tray-packed tilapia fillets stored at $0{ }^{\circ} \mathrm{C}$ based on sensory, microbiological, biochemical, and physical attributes. African Journal of Biotechnology, 9(5), 692-701. doi: 10.5897/AJB09.1369

Lopez-Caballero, M. E., Gómez-Guillén, M. C., Pérez Mateos, M., \& Montero, P. (2005). A chitosan-gelatin blend as a coating for fish patties. Food Hydrocolloids, 19(2), 303311. doi: 10.1016/j.foodhyd.2004.06.006

Maqsood, S., Benjakul, S., \& Shahidi, F. (2013). Emerging role of phenolic compounds as natural food additives in fish and fish products. Critical Reviews in Food Science and Nutrition, 53(2), 162-179. doi: 10.1080/10408398. 2010.518775

Maturin, L., \& Peeler, J. T. (2001). Laboratory Methods - BAM: Aerobic Plate Count. US Food and Drug Administration. https://www.fda.gov/Food/FoodScienceResearch/ LaboratoryMethods/ucm063346.htm

Mi, H., Zhao, B., Wang, C., Xu, Y., Ma, Y., Mao, L., \& Li, J. (2017). Effect of chitosan coating enriched with 6-gingerol on red drum fillets quality and shelf life during refrigerated storage. Journal of Aquatic Food Product Technology, 26(9), 1032-1041. doi: 10.1080/10498850.2017.1375587

Morachis-Valdez, A. G., Gómez-Oliván, L. M., García-Argueta, I., Hernández-Navarro, M. D., Díaz-Bandera, D., \& DublánGarcía, O. (2017). Effect of chitosan edible coating on the biochemical and physical characteristics of carp fillet (Cyprinus carpio) stored at " $18{ }^{\circ} \mathrm{C}$. International Journal of Food Science. doi: 10.1155/2017/2812483

Nejib, G., Moza Abdallah, A. B., Ismail Mohammed, A. B., Ann, M., \& Mohammad, S. R. (2005). The effect of storage temperature on histamine production the freshness of yellow fin tuna (Thunnus albacares). Food Research International, 38(2), 215-222. doi: 10.1016/j.foodres.2004.09.011

No, H. K., Meyers, S. P., Prinyawiwatkul, W., \& Xu, Z. (2007). Applications of chitosan for improvement of quality and shelf life of foods: a review. Journal of Food Science, 72, 87100.

Ojagh, S. M., Rezaei, M., Razavi, S. H., \& Hosseini, S. M. H. (2010). Effect of chitosan coatings enriched with cinnamon oil on the quality of refrigerated rainbow trout. Food Chemistry, 120(1), 193-198. doi: 10.1016/j.foodchem. 2009.10.006

Saito, T., Arai, K., \& Matsuyoshi, M. (1959). A new method for estimating the freshness of fish. Bulletin of the Japanese Society of Scientific Fisheries, 24(9), 749-750.

Sathivel, S. (2005). Chitosan and protein coatings affect yield, moisture loss, lipid oxidation of pink salmon (Oncorhynchus gorbushcha) fillets during frozen storage. Journal of Food Science, 70(8), e455-e459. doi: 10.1111/j.1365-2621. 2005. tb11514.x

Sathivel, S., Liu, Q., Huang, J., \& Prinyawiwatkul, W. (2007). The influence of chitosan glazing on the quality of skinless pink salmon (Oncorhynchus gorbuscha) fillets during frozen storage. Journal of Food Engineering, 83(3), 366-373. doi: 10.1016/j.jfoodeng.2007.03.009

Soares, N. M., Mendes, T. S., \& Vicente, A. A. (2013). Effect of chitosan-based solutions applied as edible coatings and water glazing on frozen salmon preservation-a pilot-scale study. Journal of Food Engineering, 119(2), 316-323. doi: 10.1016/ j.jfoodeng.2013.05.018

Sriket, P., \& La-ongnual, T. (2018). Quality changes and discoloration of Basa (Pangasius bocourti) fillet during frozen storage. Journal of Chemistry, 2018, 1-7. doi: 10.1155/ 2018/5159080

Vásconez, M. B., Flores, S. K., Campos, C. A., Alvarado, J., \& Gerschenson, L. N. (2009). Antimicrobial activity and physical properties of chitosan-tapioca starch based edible films and coatings. Food Research International, 42(7), 762769.

Wenjiao, F., Yongkui, Z., Pan, D., \& Yuwen, Y. (2013). Effects of chitosan coating containing antioxidantof bamboo leaves on qualitative properties and shelf life of silver carp during chilled storage. Czech Journal of Food Science, 31, 451456.

Yokoyama, Y., Sakaguchi, M., Kawai, F., \& Kanamori, M. (1992). Changes in concentration of ATP-related compounds in various tissues of oyster during ice storage. Nippon Suisan Gakkaishi, 58, 2125-2136. 